\title{
Purification of a Synthetic Pterocarpanquinone by Countercurrent Chromatography
}

\author{
Fernanda das Neves Costa, ${ }^{*}, a$ Alcides José M. da Silva, ${ }^{a}$ Chaquip Daher Netto, ${ }^{b}$ \\ Jorge L. de Oliveira Domingos, ${ }^{a}$ Paulo Roberto R. Costa ${ }^{a}$ and Gilda G. Leitão ${ }^{a}$
}

${ }^{a}$ Núcleo de Pesquisas de Produtos Naturais, Centro de Ciências da Saúde, Bloco H, Universidade Federal do Rio de Janeiro, 21941-590 Rio de Janeiro-RJ, Brazil

${ }^{b}$ Instituto de Química, Universidade Federal do Rio de Janeiro, campus Macaé, 27930-560 Macaé-RJ, Brazil

\begin{abstract}
A cromatografia contracorrente (CCC) foi empregada como uma alternativa útil, rápida e econômica às técnicas cromatográficas convencionais na purificação de uma pterocapanoquinona sintética, LQB 118. A separação foi feita em duas etapas utilizando o sistema de solvente hexanoclorofórmio-metanol-água 2:1,5:5:2 em ambas as etapas. A purificação tradicional deste produto por cromatografia em coluna utilizando gel de sílica como fase estacionária requer a utilização de grande quantidade de solvente, sendo bastante demorada, além de permitir a adsorção da substância na coluna. $\mathrm{O}$ uso de ${ }^{1} \mathrm{H}$ RMN para o cálculo do $\mathrm{K}_{\mathrm{D}}$ da substância alvo foi proposto como uma alternativa às medidas por CLAE.
\end{abstract}

Countercurrent chromatography (CCC) was employed as a useful, fast and economic alternative to conventional chromatography techniques for the purification of a synthetic pterocarpanquinone, LQB-118. The separation was performed in a two-step CCC with the solvent system hexanechloroform-methanol-water 2:1.5:5:2 in both steps. Traditional purification of these reaction products by silica gel column chromatography demanded a large amount of solvent and time, besides allowing the irreversible adsorption of the compound in the column. The use of ${ }^{1} \mathrm{H}$ NMR for the calculation of $\mathrm{K}_{\mathrm{D}}$ of target compound is proposed as an alternative for HPLC measurements.

Keywords: countercurrent chromatography, pterocarpanquinone, flash chromatography, distribution coefficient $\left(\mathrm{K}_{\mathrm{D}}\right)$

\section{Introduction}

The pterocarpanquinones comprise a new group of antineoplasic and antiparasitic prototypes. The first compounds of this series were designed and synthesized in our laboratory some years ago. ${ }^{1}$ These compounds showed antineoplasic activity in cultured breast cancer, ${ }^{1,2}$ leukemia ${ }^{3,4}$ and lung cancer cell lines ${ }^{4}$ with some of these cell lines presenting multifatorial drug resistance (MDR) phenotype. These pterocarpanquinones also showed antileishmanial and antimalarial activity on Leishmania amazonensis and Plasmodium falciparum in culture respectively. ${ }^{2}$ Pterocarpanquinone LQB-118 (Figure 1) is the most promising compound of this series. The antineoplasic action of LQB-118 on chronic myeloid leukemia was further

*e-mail: farmfcosta@yahoo.com.br studied and this compound led to significant apoptosis rate in cells from patients with chronic myeloid leukemia in treatment in the National Institute of Cancer (INCA) in Rio de Janeiro. ${ }^{5}$ These cells exhibit MDR phenotype such as P-glycoprotein, MRP1 and p53 overexpression. ${ }^{6,7}$ LQB-118 and some derivatives were patented. ${ }^{8} \mathrm{LQB}-118$ also showed anticancer activity ${ }^{4}$ and antileishmanial activity ${ }^{9}$ in mice.

LQB-118 was synthesized through a new palladiumcatalyzed oxyarylation (oxa-Heck) reaction of

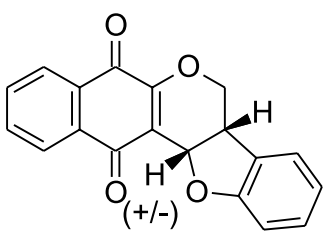

LQB 118

Figure 1. $( \pm)-L Q B-118$. 
<smiles>O=C1c2ccccc2C(=O)C2OCC=CC12</smiles>

Chromenquinone, 1

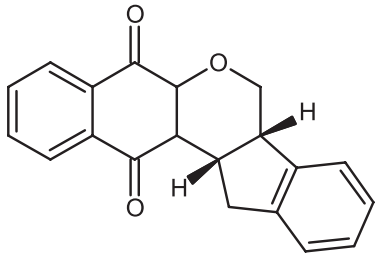

LQB-118
Figure 2. Synthesis of LQB-118. i: orho-iodophenol, 2, $\mathrm{Pd}(\mathrm{OAc})_{2}$, $\mathrm{Ag}_{2} \mathrm{CO}_{3}$, acetone, reflux, $39 \%$.

chromenquinone $\mathbf{1}$ by ortho-iodophenol $\mathbf{2}$ in the absence of ligands (Figure 2). ${ }^{4}$ After flash chromatography, the product was obtained as a yellow solid in $39 \%$ yield.

Adsorption chromatography on silica gel is the most popular and widely used method for purification of organic synthetic products. However, this solid support has a tendency to strongly adsorb polar compounds and can cause chemical structure modifications, besides being laborious, time consuming and requiring the use of a large amount of solvent. LQB-118 is a polar compound and its purification by chromatography in silica gel generates much residual solvent and spending several hours. Therefore, a more efficient method for the purification of this compound needs to be developed.

Countercurrent chromatography (CCC), on the other hand, has become an effective alternative to conventional chromatographic techniques because it is a liquid-liquid partition chromatography technique, which does not use a solid support, eliminating irreversible adsorption of samples and maintaining their chemical structure. ${ }^{10-12}$ Separation in CCC are generally based on the partitioning of solutes between two immiscible liquid phases being the relative proportions of solute in each phase is determined by the respective distribution coefficient, $\mathrm{K}_{\mathrm{D}} \cdot{ }^{13,14} \mathrm{CCC}$ can be used for the separation of samples of a wide polarity range but has special advantages for the handling of polar compounds. ${ }^{15}$ So far, less attention has been given to the purification of organic synthetic products by $\mathrm{CCC}^{16-23}$ in contrast to the isolation of natural products..$^{14,24-28}$

The present work describes an efficient method for purification of LQB-118 (Figure 1) using CCC and compares this purification with that on silica gel column chromatography previously used. ${ }^{4}$ The $\mathrm{K}_{\mathrm{D}}$ of the target compound were calculated using ${ }^{1} \mathrm{H}$ NMR.

\section{Experimental}

Apparatus

Preparative high-speed counter-current chromatography (HSCCC) was performed on a Quattro HT-Prep countercurrent chromatograph (AECS, Bridgend, United Kingdom) equipped with two holders containing two polytetrafluoroethylene multi-layer coils each $(26 \mathrm{~mL}$, $1.0 \mathrm{~mm}$ i.d. $+234 \mathrm{~mL}, 3.2 \mathrm{~mm}$ i.d. and $95 \mathrm{~mL}, 2.0 \mathrm{~mm}$ i.d. + $98 \mathrm{~mL}, 2.0 \mathrm{~mm}$ i.d.). The rotation speed is adjustable up to $865 \mathrm{rpm}$. The HSCCC system was connected to a constant flow pump Series II (Scientific Systems Inc., Lab Alliance) and a Merck fraction collector L-7650 (Merck, Darmstadt, Germany). A $5 \mathrm{~mL}$ sample loop was used to inject the sample.

${ }^{1} \mathrm{H}$ NMR data measurements of synthetic compounds purified from HSCCC were recorded on a Varian 400-MR (California, USA) at $25^{\circ} \mathrm{C}$, operating at $400 \mathrm{MHz}$ for ${ }^{1} \mathrm{H}$. NMR spectra were recorded in chloroform $\left(\mathrm{CDCl}_{3}\right)$, using TMS and methanol as internal standard.

\section{Materials and reagents}

Organic solvents used for HSCCC separation were of HPLC grade and purchased from Tedia Brazil (Rio de Janeiro, Brazil). All aqueous solutions were prepared with pure water produced by Milli-Q water (18.2 M 2 ) system.

Flash chromatography was performed with $25 \mathrm{~g}$ of silica gel 230-400 mesh (Aldrich), packed into a glass column $(35 \mathrm{~cm} \times 2 \mathrm{~cm}$ i.d.). The bed volume was about $120 \mathrm{~mL}$.

\section{Synthesis and purification on silica gel}

To a stirred solution of chromenequinone $(2.97 \mathrm{~g}$, $14 \mathrm{mmol})$ in acetone $(90 \mathrm{~mL})$, ortho-iodophenol $(3.7 \mathrm{~g}$, $16.8 \mathrm{mmol})$, and $\mathrm{Pd}(\mathrm{OAc})_{2}(316.6 \mathrm{mg}, 1.4 \mathrm{mmol}, 10 \mathrm{~mol} \%)$ were added. The reaction mixture was refluxed for $4 \mathrm{~h}$ and filtered in Celite with ethyl acetate. The organic layer was washed with brine, dried over anhydrous $\mathrm{Na}_{2} \mathrm{SO}_{4}$ and concentrated under reduced pressure. The crude product $(2 \mathrm{~g})$ was washed in $n$-hexane for $48 \mathrm{~h}$. After flash chromatography using $n$-hexane/ethyl acetate (95:5) as eluent, the LQB-118 was obtained as a yellow solid in 39\% yield (1.61 g), mp $145^{\circ} \mathrm{C}$ (Figure 2). Under these conditions $10 \mathrm{~L}$ of the solvent mixture was used and the process took around $8 \mathrm{~h}$.

\section{Selection of two-phase solvent system}

A number of two-phase solvent systems were tested by changing the volume ratio of the solvents in the system to obtain the optimum composition that gave suitable distribution coefficient $\left(\mathrm{K}_{\mathrm{D}}\right)$. The solvent systems tested were hexane-chloroform-methanol-water ranging from $2: 4: 5: 2,2: 5: 5: 2$ to $2: 6: 5: 2$. Small amounts of the sample were dissolved in a small test tube containing the equilibrated two-phase solvent system. The test tubes were shaken and the compounds allowed to partition between the two phases. Equal aliquots of each phase were spotted 
beside each other separately on silica gel TLC plates (Merck Art. 05554, Darmstadt, Germany), developed with hexane-ethyl acetate, 7:3. The results were visualized under UV light $(254 \mathrm{~nm})$. Distribution coefficient $\left(\mathrm{K}_{\mathrm{D}}\right)$ of the target compound was calculated as follows: the target compound was dissolved into the promising solvent system (concentrations: $0.5,0.7$ and $1.0 \mathrm{mg} \mathrm{mL}^{-1}$ ) and, after equilibrium of the phases was achieved, the upper and the lower layers were taken separately and evaporated in a rotary evaporator under reduced pressure. The residues were dissolved in $0.6 \mathrm{~mL}$ of deuterated chloroform and $0.01 \mathrm{~mL}$ of methanol and then, analyzed by ${ }^{1} \mathrm{H}$ NMR. The $\mathrm{K}_{\mathrm{D}}$ value was expressed as the peak area of the compound in the stationary phase divided by the peak area of the compound in the mobile phase. We have chosen the doublet in $5.66 \mathrm{ppm}$ which corresponds to ${ }^{1} \mathrm{H},{ }^{4}$ as it was a simplified peak. The peak area of the compound was obtained after integrating the peak of methanol as 1 . The $\mathrm{K}_{\mathrm{D}}$ of the target compound was obtained from the average of $\mathrm{K}_{\mathrm{D}}$ values of the different concentrations.

\section{Preparation of two-phase solvent system and sample solution}

The selected solvent systems were thoroughly equilibrated in a separatory funnel at room temperature. The two phases were separated shortly before use and degassed by sonication for $15 \mathrm{~min}$. The organic lower phase was used as stationary phase while aqueous upper phase was used as mobile phase, head to tail direction, reversed elution mode. The sample solution was prepared by dissolving the sample ( $1 \mathrm{~g}$ of the crude reaction products) in $5 \mathrm{~mL}$ of the solvent mixture of aqueous and organic phases $(1: 1 \mathrm{v} / \mathrm{v})$ of the solvent system used for HSCCC separation.

\section{CCC separation procedure}

In each step of the two-step separation procedure, the coil was first entirely filled with the stationary phase, and then the apparatus was rotated at $865 \mathrm{rpm}$, while the mobile phase was pumped into the column in a $2 \mathrm{~mL} \mathrm{~min}^{-1}$ flow rate. After the mobile phase front emerged $(\mathrm{Vm}=13 \mathrm{~mL})$ and hydrodynamic equilibrium was established in the column $\left(\mathrm{S}_{\mathrm{F}}=87 \%\right), 5 \mathrm{~mL}$ of the sample solution was injected into the $98 \mathrm{~mL}$ column through the injection valve (Rheodyne model 5020, USA).

Purity analysis of the synthetic pterocarpanquinone

Purity of the synthetic pterocarpanquinone isolated by CCC was calculated by HPLC with a Lachron Merck HPLC
(Merck, Darmstadt, Germany) equipped with an interface D-7000, pump L-7100, diode array detector (DAD) L-7450A and solvent degasser L-7612. The injections were done manually with an injecton valve equipped with a $20 \mu \mathrm{L}$ sample loop. A Lichrosorb RP-18 column (5 $\mu \mathrm{m}$ particle size, $250 \times 4.6 \mathrm{~mm}$ i.d.) was used. The mobile phase used was isocratic $\mathrm{MeOH}$ in $15 \mathrm{~min}$, the flow-rate was $1 \mathrm{~mL} \mathrm{~min}^{-1}$ and detection was done at $240 \mathrm{~nm}$.

\section{Results and Discussion}

The separation of LQB-118 by silica gel column chromatography is effective but is laborious, time consuming and requires the use of large amount of solvent. ${ }^{4}$ HSCCC was used as an alternative, more economic, efficient and eco-friendly method.

Choosing the correct solvent system is the most important step in CCC separation and some basic requirements such as settlings times, distribution coefficient $\left(\mathrm{K}_{\mathrm{D}}\right)$ and solubility of target compounds should be taken into account. ${ }^{13,14}$ We selected a two-phase solvent system composed of hexane-ethyl acetate-methanol-water (HEMWat) to start our tests because this composition covers a broad range of versatility and polarity by modifying the volume ratio of the four solvents. ${ }^{29}$ However, in none of the tested ranges good solubility was achieved. As LQB-118 is more soluble in chlorinated solvents than in EtOAc, the latter was substituted by $\mathrm{CHCl}_{3}$ and the system hexane-chloroform-methanol-water was tested for better solubility of the sample. The exchange of EtOAc by chloroform changes the solvent system family and the logical way of getting the correct system for the isolation of the target compound.

The solvent system family composed of $\mathrm{CHCl}_{3}-\mathrm{MeOH}-$ $\mathrm{H}_{2} \mathrm{O}$ is useful for the separation of very high polarity compounds and modifications on this system can be done by adding hexane, as a fourth solvent, lowering a little its polarity, allowing the separation of less polar compounds.

This system $\left(\mathrm{CHCl}_{3}-\mathrm{MeOH}-\mathrm{H}_{2} \mathrm{O}\right)$ consists of two immiscible solvents plus a third one, miscible with the other two. ${ }^{30}$ The third solvent should be partitioned between the other two in the same way as one would expect the target compound to do. ${ }^{30,31}$ If this solvent system is to be used, the first step is to check if the sample is soluble in $\mathrm{MeOH}$ (named by A. Foucault as the 'best solvent'). The next step is the partitioning of this solvent between the other two, $\mathrm{CHCl}_{3}$ and $\mathrm{H}_{2} \mathrm{O}$. We should bear in mind, however, that $\mathrm{MeOH}$ acts as an aqueous modifier and if the sample is distributed mainly at the aqueous phase than at the organic phase, alterations in the ratio of 
the 'best solvent' will not be effective. ${ }^{27}$ Hexane should be added only later to modulate the partition of the target compound in the organic layer.

$\mathrm{CHCl}_{3}-\mathrm{MeOH}-\mathrm{H}_{2} \mathrm{O}$ was tested in ratios $\mathrm{X}: 5: 2, \mathrm{X}$ being 4, 5 and 6. LQB-118 was more retained in the organic layer in the three systems, so hexane was added in order to decrease the solubility of the target compound in organic layer, so that a good $\mathrm{K}_{\mathrm{D}}$ value can be achieved. $\mathrm{Hex}-\mathrm{CHCl}_{3}-\mathrm{MeOH}-\mathrm{H}_{2} \mathrm{O}$ was tested ranging from 2:4:5:2 (1); 2:5:5:2 (2) to 2:6:5:2 (3) (Figure 3). In composition (1) LQB-118 was more retained in lower aqueous phase, being necessary to increase the chloroform ratio aiming the equal distribution of the target compound between the two phases. In solvent system (2), LQB-118 was slightly more retained in the lower organic phase - phases changed because of density of chlorinated solvents - and when further increasing the ratio of chloroform, in system (3), the target compound was more strongly retained in lower organic phase. Then, $\mathrm{K}_{\mathrm{D}}$ of pterocarpanequinone in system (2) was calculated using ${ }^{1} \mathrm{H}$ NMR, being 1.88 .

The solvent system ( $\mathrm{Hex}-\mathrm{CHCl}_{3}-\mathrm{MeOH}-\mathrm{H}_{2} \mathrm{O}$, 80:200:200:80 mL) was then employed for the semipreparative separation of $1 \mathrm{~g}$ of crude reaction product in a HT-Prep Quattro CCC with a $98 \mathrm{~mL}$ volume and $2.0 \mathrm{~mm}$

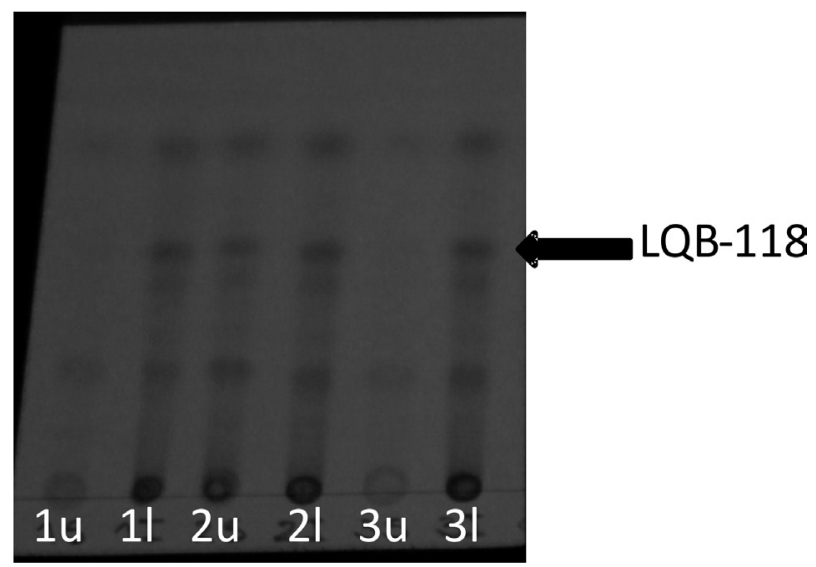

Figure 3. TLC of test tube partitioning test $(\mathrm{u}=$ upper phase, $1=$ lower phase). Solvent system tested: hexane-chloroform-methanol-water 2:4:5:2 (1); 2:5:5:2 (2) and 2:6:5:2 (3). Mobile phase: hexane-ethyl acetate 7:3. Results were visualized under UV light $(254 \mathrm{~nm})$.

i.d. column. Fifty fractions of $4 \mathrm{~mL}$ were collected and then, the stationary phase was fractionated. This procedure resulted in the purification of the pterocarpanquinone in fractions 32-54 (547.2 mg, 96.3\% purity, Figure 4). This fraction was further purified by CCC in the same conditions. The purified pterocarpanquinone $(491.1 \mathrm{mg}, 99.0 \%$ purity, Figure 5) was isolated in fractions 34-50.

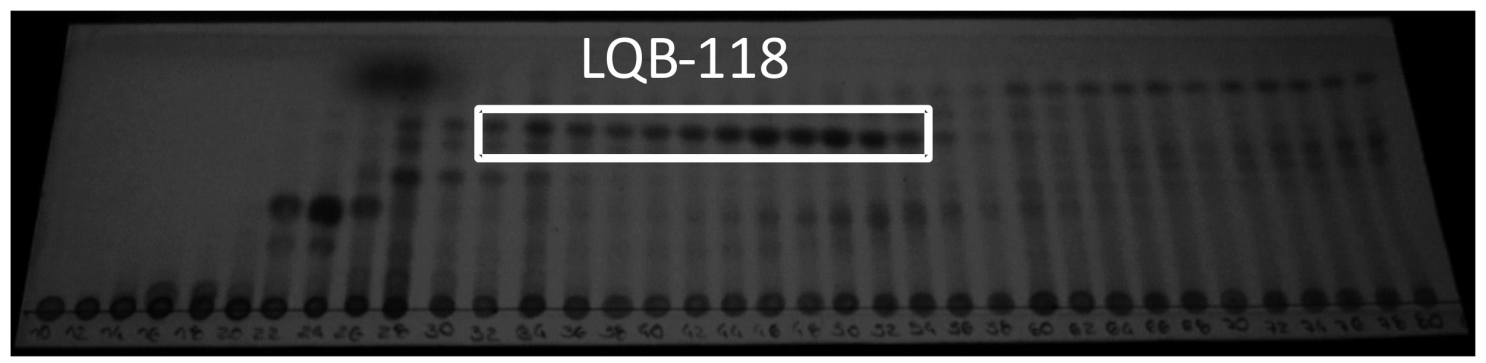

Figure 4. TLC analyses of HSCCC fractions; mobile phase: hexane-ethyl acetate, 7:3; results were visualized under UV light (254 nm).

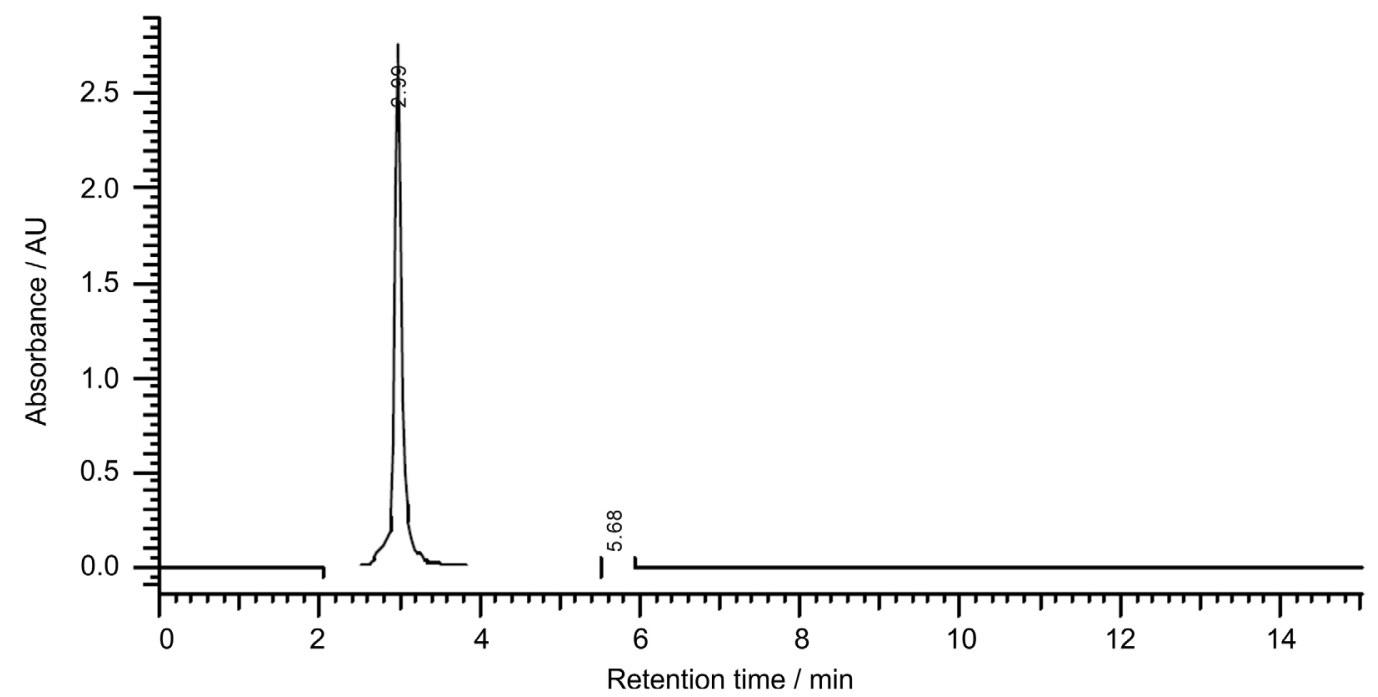

Figure 5. HPLC chromatogram of the purified LQB-118. 


\section{Conclusions}

The synthetic pterocarpanquinone LQB-118 has been tested in vitro with successes for the treatment of chronic myeloid leukemia. We have shown before that this compound could be purified by flash chromatography using large amount the solvent and the process took around $8 \mathrm{~h}$. This work demonstrates the use of CCC as an alternative to usual chromatographic techniques, such as silica gel column chromatography, in the purification of organic synthetic products. The economy of time and organic solvent is remarkable, besides avoiding adsorption of polar samples and maintaining their chemical structure. ${ }^{1} \mathrm{H}$ NMR technique proved to be a useful and quick methodology to calculate $\mathrm{K}_{\mathrm{D}}$ of target compounds.

\section{Acknowledgments}

We are grateful for financial support from $\mathrm{CNPq}$, and FAPERJ and CAPES for a fellowship.

\section{References}

1. da Silva, A. J. M.; Buarque, C. D.; Brito, F. V.; Aurelian, L.; Macedo, L. F.; Malkas, L. H.; Hickey, R. J.; Lopes, D. V. S.; Nöel, F.; Murakami, Y. L. B.; Silva, N. M. V.; Melo, P. A.; Caruso, R. R. B.; Castro, N. G.; Costa. P. R. R.; Bioorg. Med. Chem. 2002, 10, 2731.

2. da Silva, A. J. M.; Netto, C. D.; Pacienza-Lima, W.; TorresSantos, E. C.; Rossi-Bergmann, B.; Maurel, S.; Valentin, A.; Costa, P. R. R.; J. Braz. Chem. Soc. 2009, 20, 176.

3. Salustiano, E. J. S.; Netto, C. D.; Fernandes, R. F.; da Silva, A. J. M.; Bacelar, T. S.; Castro, C. P.; Buarque, C. D.; Maia, R. C.; Rumjanek, V. M.; Costa, P. R. R.; Invest. New Drugs 2010, 28, 139 .

4. Netto, C. D.; da Silva, A. J. M.; Salustiano, E. J. S.; Bacelar, T. S.; Riça, I. G.; Cavalcante, M. C. M.; Rumjanek, V. M.; Costa, P. R. R.; Bioorg. Med. Chem. 2010, 18, 1610.

5. Maia, R. C.; Vasconcelos, F. C.; Bacelar, T. S.; Salustiano, E. J.; da Silva, L. F. R.; Pereira, D. L.; Moellman-Coelho, A.; Netto, C. D.; da Silva, A. J. M.; Rumjanek, V. M.; Costa, P. R. R.; Invest. New Drugs 2011, 29, 1143. doi:10.1007/s10637-010-9453-z.

6. Rumjanek, V. M.; Trindade, G. S.; Wagner-Souza, K.; deOliveira, M. C.; Marques-Santos, L. F.; Maia, R. C.; Capella, M. A.; An. Acad. Bras. Cienc. 2001, 73, 57.

7. Maia, R. C.; Wagner, K.; Cabral, R. H.; Rumjanek, V. M.; Cancer Lett. 1996, 106, 101.

8. Costa, P. R. R.; da Silva, A. J. M.; Rumjanek, V. M.; RossiBergmann, B.; Salustiano, E. J.; Netto, C. D.; Buarque, C. D.;
Pacienza-Lima, W.; Torres-Santos, E. C.; Cavalcante, M. D. M.; Seabra, S. H.; Riça, I. G.; Patent Numbers: WO2010054452-A1; BR200806047-A2. Patent Assignees and Codes: Univ. Rio de Janeiro (UYRI-Non-standard)

9. Cunha-Júnior, E. F.; Pacienza-Lima, W.; Ribeiro, G. A.; Netto, C. D.; do Canto-Cavalheiro, M. M.; da Silva, A. J. M.; Costa, P. R. R.; Rossi-Bergman, B.; Torres-Santos, E. C.; J. Antimicrob. Chemother. 2011, 66, 1555.

10. Berthod, A. In Advances in Chromatography, Grushka, E.; Grinberg, N., eds.; Taylor \& Francis Inc.: NY, 2009, vol. 47.

11. Ito, Y.; J. Chromatogr., A 2005, 1065, 145.

12. Conway, W. D.; Counter-Current Chromatography: Apparatus, Theory and Applications, VCH Publishers Inc.: NY, 1990.

13. Marston, A.; Hostettmann, K.; J. Chromatogr., A 1994, 658, 315.

14. Marston, A.; Hostettmann, K.; J. Chromatogr., A 2006, 1112, 181.

15. Sticher, O.; Nat. Prod. Rep. 2008, 25, 517.

16. Knight, M.; Tamminga, C. A.; Ito, Y.; Gardner, J. D.; Chase, T. N.; J. Chromatogr. 1984, 301, 277.

17. Knight, M.; Ito, Y.; Peters, P.; DiBello, C.; J. Liq. Chromatogr. 1985, 8, 2281.

18. Weisz, A.; Markey, S. P.; Ito, Y.; J. Chromatogr. 1986, 383, 132.

19. Mandava, N. B.; Ito, Y.; Ma, Y.; J. Liq. Chromatogr. Relat. Technol. 1998, 21, 217.

20. Whiteside, R. G.; Games, D. E.; Strawson, C.; Graham, A. S.; Brown, L.; J. Liq. Chromatogr. Relat. Technol. 2001, 24, 1801.

21. Duret, P.; Fakhfakh, M. A.; Herrenknecht, C.; Fournet, A.; Franck, X.; Figadere, B.; Hoquemiller, R.; J. Chromatogr., A 2003, 1011, 55.

22. Silva, R. S. F.; Leitão, G. G.; Brum, T. B.; Lobato, A. P. G.; Pinto, M. C. F. R.; Pinto, A. V.; J. Chromatogr., A 2007, 1151, 197.

23. Wagenaar, F. L.; Hochlowski, J. E.; Pan, J. Y.; Tu, N. P.; Searle, P. A.; J. Chromatogr., A 2007, 1216, 4154.

24. Schaufelberger, C. D.; J. Chromatogr., A 1991, 538, 45.

25. Drasar, P.; Moravcova, J.; J. Chromatogr., B: Anal. Technol. Biomed. Life Sci. 2004, 812, 3.

26. Sutherland, I. A.; Fisher, D.; J. Chromatogr., A 2009, 1216, 740.

27. Costa, F. N.; Leitão, G. G.; J. Sep. Sci. 2010, 33, 336.

28. Di, D.-L.; Zheng, Y. Y.; Chen, X. F.; Huang, X.-Y.; Feng, S.-L.; Chinese J. Anal. Chem. 2011, 39, 269.

29. Oka, F.; Oka, H.; Ito, Y.; J. Chromatogr. 1991, 538, 99.

30. Focault, A. P.; Centrifugal Partition Chromatography, Chromatographic Science Series, Marcel Dekker: NY, 1994.

31. Focault, A. P.; Chevolot, L.; J. Chromatogr., A 1998, 808, 3.

Submitted: August 21, 2011

Published online: May 24, 2012 